\title{
Cytotoxicity of the methanol extracts of Elephantopus mollis, Kalanchoe crenata and 4 other Cameroonian medicinal plants towards human carcinoma cells
}

\author{
Victor Kuete ${ }^{1,3^{*}}$, Fabrice W. Fokou², Oğuzhan Karaosmanoğlư ${ }^{3}$, Veronique P. Beng ${ }^{2}$ and Hülya Sivas ${ }^{3}$
}

\begin{abstract}
Background: Cancer still constitutes one of the major health concerns globally, causing serious threats on patients, their families, and the healthcare system.

Methods: In this study, the cytotoxicity of the methanol extract of Elephantopus mollis whole plant (EMW), Enantia chlorantha bark (ECB), Kalanchoe crenata leaves (KCL), Lophira alata bark (LAB), Millettia macrophylla leaves (MML) and Phragmanthera capitata leaves (PCL) towards five human solid cancer cell lines and normal CRL2120 fibroblasts, was evaluated. Extracts were subjected to qualitative chemical screening of their secondary metabolite contents using standard methods. The cytotoxicity of samples was evaluated using neutral red uptake (NR) assay meanwhile caspase activation was detected by caspase-Glo assay. Flow cytometry was used to analyze the cell cycle distribution and the mitochondrial membrane potential (MMP) whilst spectrophotometry was used to measure the levels of reactive oxygen species (ROS).

Results: Phytochemical analysis revealed the presence of polyphenols, triterpenes and sterols in all extracts. The $I_{50}$ values of the best samples ranged from $3.29 \mu \mathrm{g} / \mathrm{mL}$ (towards DLD-1 colorectal adenocarcinoma cells) to 24. $38 \mu \mathrm{g} / \mathrm{mL}$ (against small lung cancer A549 cells) for EMW, from $2.33 \mu \mathrm{g} / \mathrm{mL}$ (mesothelioma SPC212 cells) to 28. $96 \mu \mathrm{g} / \mathrm{mL}$ (HepG2 hepatocarcinoma) for KCL, and from $0.04 \mu \mathrm{g} / \mathrm{mL}$ (towards SPC212 cells) to $0.55 \mu \mathrm{g} / \mathrm{mL}$ (towards A549 cells) for doxorubicin. EMW induced apoptosis in MCF-7 cells mediated by MMP loss and increased ROS production whilst KCL induced apoptosis via ROS production.

Conclusion: This study provides evidences of the cytotoxicity of the tested plant extract and highlights the good activity of Elephantopus mollis and Kalanchoe crenata. They deserve more exploration to develop novel cytotoxic drugs.
\end{abstract}

Keywords: Cameroon, Carcinoma, Cytotoxicity, Elephantopus mollis, Kalanchoe crenata, Mode of action

\section{Background}

Cancer still constitutes a major health concern globally, causing serious threats on patients, their families, and the healthcare system. The related economic impact is significant and is increasing, with annual cost in 2010 being estimated at about 1.16 trillion US dollars [1].

\footnotetext{
* Correspondence: kuetevictor@yahoo.fr

'Department of Biochemistry, Faculty of Science, University of Dschang Dschang, Cameroon

${ }^{3}$ Department of Biology, Science Faculty, Anadolu University, Eskişehir, Turkey Full list of author information is available at the end of the article
}

About $70 \%$ of deaths caused by cancer occur in low- and middle-income countries. Chemotherapy is recognized as the major mode of treatment of malignant diseases, and the plant kingdom has been the origin of many cytotoxic drugs such as paclitaxel (from Taxus brevifolia) and Vinca alkaloids (from Catharanthus roseus) [2-5]. The potential of African flora as a source of a variety of cytotoxic agents is intensively being demonstrated $[6,7]$. In fact, various cytotoxic plants of the continent were reported amongst which are Anthocleista schweinfurthii, Morus mesozygia, Nauclea latifolia, Erythrina sigmoidea 
[8], Erythrina sacleuxii, Albizia gummifera, Strychnos usambarensis, Zanthoxylum gilletii, Bridelia micrantha, Croton sylvaticus, Albizia schimperiana, Erythrina burttii, Erythrina sacleuxii, Bridelia micarantha, Zanthoxylum giletii and Solanum aculeastrum [9]. In our continuous search for cytotoxic agents from African flora, this study was undertaken to evaluate the antiproliferative activity of the methanol extracts of six Cameroonian plants used traditionally to treat cancers or disease states with symptoms related to cancer. These plants included Enantia chlorantha Oliv. (Annonaceae), Elephantopus mollis Kunth (Asteraceae), Kalanchoe crenata (Andrews) Haworth (Crassulaceae), Lophira alata Banks ex C.F.Gaertn.(Ochnaceae), Millettia macrophylla Benth. (Fabaceae) and Phragmanthera capitata (Spreng.) Balle (Loranthaceae). The study was extended to the assessment of the mode of action of the best extracts, namely those from Elephantopus mollis whole plant (EMW) and Kalanchoe crenata leaves (KCL).

\section{Methods}

\section{Plant material and extraction}

Plants studied in this work are used in the traditional medicine to treat cancer or disease states with symptoms related to cancer (Table 1). They were collected in different parts of Cameroon in February 2015 and included barks of Lophira alata and Enantia chlorantha, leaves of Phragmanthera capitata, Kalanchoe crenata and Millettia macrophylla and the whole plant of Elephantopus mollis. The identification of palnts was done by the Cameroon National Herbarium (HNC; Yaounde) and voucher specimens are availaible under accession numbers (Table 1). The powder obtained from each air dried plant sample $(300 \mathrm{~g})$ was macerated in methanol $(\mathrm{MeOH}, 1 \mathrm{~L})$ for $48 \mathrm{~h}$ at room temperature. The macerate was further concentrated under reduced pressure to obtain the crude extract. All extracts were then conserved at $4{ }^{\circ} \mathrm{C}$.

\section{Phytochemical investigations}

Various classes of secondary metabolites including anthraquinones (Borntrager's test), alkaloids (Dragendorff's and Mayer's tests), coumarins (Lacton test), flavonoids (Aluminum chloride test), polyphenols (Ferric chloride test), saponins (Foam test), sterols (Salkowski's test), triterpenes (Libermann Burchard's test) and tannins (Gelatin test) were detected using described phytochemical methods [10-13].

\section{Chemicals}

The reference drug used in this work was doxorubicin 98.0\%, purchased from Sigma-Aldrich (Munich, Germany).

\section{Cell lines and culture}

Five carcinoma and one normal cell lines were tested in this work. They were SPC212 human mesothelioma cell line obtained from American Type Culture Collection (ATCC) and provided by Dr. Asuman Demiroğlu Zergeroğlu (Gebze Technical University, Kocaeli, Turkey), A549 human non-small cell lung cancer (NSCLC) cell line, obtained from the Institute for Fermentation, Osaka (IFO, Japan) and provided by Prof. Dr. Tansu Koparal (Anadolu University, Eskisehir, Turkey), HepG2 hepatocarcinoma cells obtained from ATCC and MCF-7 breast adenocarcinoma cells obtained from ATCC and provided by Prof. Dr. Tansu Koparal (Anadolu University, Eskisehir, Turkey), DLD-1 colorectal adenocarcinoma cell lines obtained from ATCC and the normal CRL2120 human skin fibroblasts obtained from ATCC. The cells were maintained as a monolayer in DMEM medium (Sigma-aldrich, Munich, Germany), supplemented with $10 \%$ fetal calf serum and $1 \%$ penicillin $(100 \mathrm{U} / \mathrm{mL})$ streptomycin $(100 \mu \mathrm{g} / \mathrm{mL})$ in a humidified $5 \% \mathrm{CO}_{2}$ atmosphere at $37^{\circ} \mathrm{C}$.

\section{Neutral red (NR) uptake assay}

The cytotoxicity of samples was performed by the cheaper and sensitive NR uptake assay as previously described [14-16]. Samples were added in the culture medium so that dimethylsufoxide (DMSO) used prior for dilution, did not exceed $0.1 \%$ final concentration. Briefly, cells were detached by treatment with $0.25 \%$ trypsin/EDTA (Invitrogen, USA) and an aliquot of $1 \times 10^{4}$ cells was placed in each well of a 96-well cell culture plate (Thermo Scientific, Germany) in a total volume of $200 \mu \mathrm{L}$. The cells were allowed to attach overnight and subsequently treated with different concentrations of the extracts and doxorubicin. Each of the studied samples were immediately added in varying concentrations in additional $100 \mu \mathrm{L}$ of culture medium to obtain a total volume of $200 \mu \mathrm{L} /$ well. After $72 \mathrm{~h}$ incubation in humidified $5 \% \mathrm{CO}_{2}$ atmosphere at $37{ }^{\circ} \mathrm{C}$, the medium was removed and $200 \mu \mathrm{L}$ fresh medium containing $50 \mu \mathrm{g} / \mathrm{mL}$ NR was added to each well and incubation continued for an additional $3 \mathrm{~h}$ at $37{ }^{\circ} \mathrm{C}$ in $5 \%$ $\mathrm{CO}_{2}$ atmosphere. The dye medium was then removed and each well was then washed rapidly with $200 \mu \mathrm{L}$ phosphate buffer saline (PBS) followed by addition of $200 \mu \mathrm{L}$ of acetic acid-water-ethanol in water (1:49:50). The plates were kept for $15 \mathrm{~min}$ at room temperature to extract the dye and then shaken for a few minutes on a GFL 3012 shaker (Gesellschaft für Labortechnik mbH, Burgwedel, Germany). Absorbance was measured on ELx 808 Ultra Microplate Reader (Biotek) equipped with a $540 \mathrm{~nm}$ filter. Each assay was done at least three times, with three replicates each. The viability was evaluated based on a comparison with untreated cells. The $\mathrm{IC}_{50}$ 


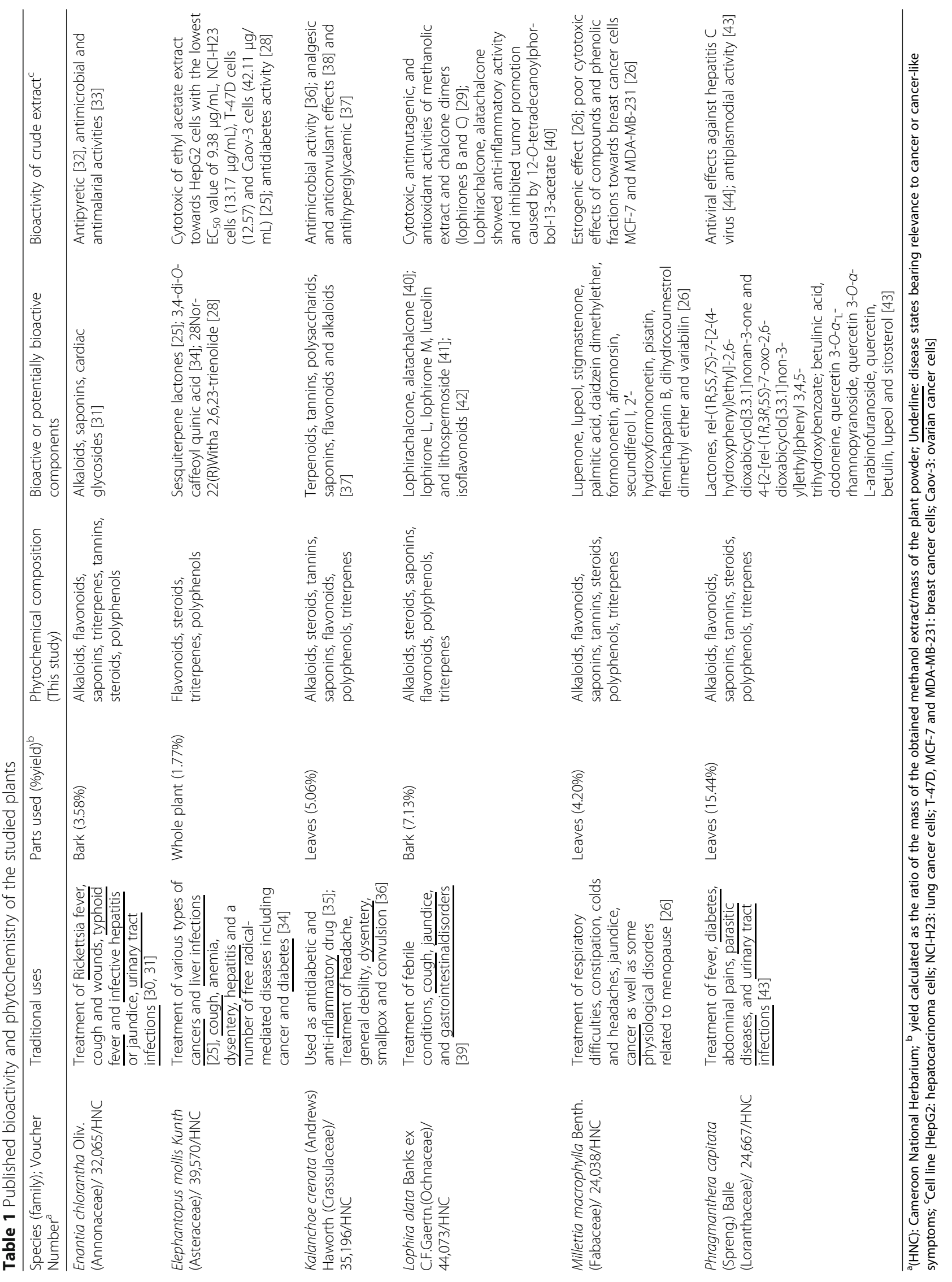


values represented the sample's concentrations required to inhibit $50 \%$ of cell proliferation and were calculated from a calibration curve by linear regression using Microsoft Excel [17].

\section{Flow cytometry for cell cycle analysis and detection of apoptotic cells}

The cell-cycle analysis was performed by flow cytometry using BD cycletest ${ }^{\mathrm{Tm}}$ Plus DNA Kit Assay (BD Biosciences, San Jose, USA). The BD Cycletest ${ }^{\text {tw }}$ Plus DNA kit provides a set of reagents for isolating and staining cell nuclei. Flow cytometric analysis of differentially stained cells is used to estimate the DNA index (DI) and cellcycle phase distributions. Briefly, MCF-7 cells $(3 \mathrm{~mL}$, $1 \times 10^{5}$ cells $/ \mathrm{mL}$ ) were seeded into each well of 6 -well plates and allowed to attach for $24 \mathrm{~h}$. The cells which were treated with $1 / 4 \times \mathrm{IC}_{50}, 1 / 2 \times \mathrm{IC}_{50}$ and $\mathrm{IC}_{50}$ concentrations of Elephantopus mollis whole plant (EMW) and Kalanchoe crenata leaves (KCL) extracts and the standard drug, doxorubicin, and grown for $72 \mathrm{~h}$. The untreated cells (control) were also included in the assay. They were further trypsinized and suspended in $1 \mathrm{~mL}$ PBS, then centrifuged at $400 \mathrm{~g}$ for $5 \mathrm{~min}$ at room temperature (RT). The cells were further processed according to the manufacturer's protocol [16]. The cells were further measured on a BD FACS Aria I Cell Sorter Flow Cytometer (Becton-Dickinson, Germany). For each sample $10^{4}$ cells were counted. For PI excitation, an argon-ion laser emitting at $488 \mathrm{~nm}$ was used. Cytographs were analyzed using BD FACSDiva ${ }^{\mathrm{Tm}}$ Flow Cytometry Software Version 6.1.2 (Becton-Dickinson).

\section{Caspase-Glo 3/7 and caspase-Glo 9 assay}

Caspase activity in MCF-7 cells was detected using Caspase-Glo 3/7 and Caspase-Glo 9 Assay kits (Promega, Mannheim, Germany) as previously reported [18-20]. Cells were treated with EMW and KCL at their $1 / 2 \times \mathrm{IC}_{50}$ and $\mathrm{IC}_{50}$ values with DMSO as solvent control for $6 \mathrm{~h}$. Luminescence was measured using an BioTek Synergy ${ }^{\text {tix }}$ HT multi-detection microplate reader. Caspase activity was expressed as percentage of the untreated control.

\section{Analysis of mitochondrial membrane potential (MMP)}

The MMP was analyzed in MCF-7 cells by $5,5^{\prime}, 6,6^{\prime}$-tetrachloro-1,1',3,3' -tetraethylbenzimidazolylcarbocyanine iodide (JC-1; Biomol, Hamburg, Germany) staining as previously reported [18-20]. Cells $\left(3 \mathrm{~mL}, 1 \times 10^{5}\right.$ cells/ $\mathrm{mL}$ ) treated for $72 \mathrm{~h}$ with different concentrations $\left(1 / 4 \times \mathrm{IC}_{50}, 1 / 2 \times \mathrm{IC}_{50}\right.$ and $\left.\mathrm{IC}_{50}\right)$ of EMW, KCL and doxorubicin (drug control) or DMSO (solvent control) were incubated with JC-1 staining solution for $30 \mathrm{~min}$ according to the manufacturer's protocol, as earlier reported. Subsequently, cells were measured in a BD FACS Aria I Cell Sorter Flow Cytometer (Becton-
Dickinson, Germany). The JC-1 signal was measured at an excitation of $561 \mathrm{~nm}(150 \mathrm{~mW})$ and detected using a 586/15 $\mathrm{nm}$ band-pass filter. The signal was analyzed at $640 \mathrm{~nm}$ excitation $(40 \mathrm{~mW})$ and detected using a 730/45 nm bandpass filter. Cytographs were analyzed using BD FACSDiva ${ }^{\text {Tx }}$ Flow Cytometry Software Version 6.1.2 (Becton-Dickinson). All experiments were performed at least in triplicates.

\section{Measurement of reactive oxygen species (ROS)}

The 2',7'-dichlorodihydrofluorescein diacetate $\left(\mathrm{H}_{2} \mathrm{DCFH}-\right.$ DA) (Sigma-Aldrich) was used for the detection of ROS in MCF-7 cells treated with EMW, KCL and doxorubicin (drug control) or DMSO (solvent control) using OxiSelect $^{\mathrm{tm}}$ Intracellular ROS Assay Kit (Green Fluorescence) as recommended by the manufacturer (Cell Biolabs Inc., San Diego, USA). This is a cell-based assay for measuring hydroxyl, peroxyl, or other reactive oxygen species activity within a cell. The assay employs the cell-permeable fluorogenic probe $2^{\prime}, 7^{\prime}$-dichlorodihydrofluorescin diacetate (DCFH-DA). DCFH-DA is diffused into cells and is deacetylated by cellular esterases to non-fluorescent $2^{\prime}, 7^{\prime}$ dichlorodihydrofluorescin (DCFH), which is rapidly oxidized to highly fluorescent $2^{\prime}, 7^{\prime}$-dichlorofluorescein $(\mathrm{DCF})$ by ROS. Cells $\left(1 \times 10^{4}\right.$ cells $)$ were treated with samples at $1 / 4 \times \mathrm{IC}_{50}, 1 / 2 \times \mathrm{IC}_{50}$ and $\mathrm{IC}_{50}$ for $24 \mathrm{~h}$. After addition of $100 \mu \mathrm{L} 1 \mathrm{X}$ DCFH-DA/DMEM solution to cells and incubation at $37{ }^{\circ} \mathrm{C}$ for $30-60 \mathrm{~min}$, the fluorescence was measured using SpectraMax ${ }^{\oplus}$ M5 Microplate Reader (Molecular Devices, Biberach, Germany) at $480 / 530 \mathrm{~nm}$. All experiments were performed at least in triplicates.

\section{Results}

Phytochemical composition of plants' extracts

Table 1 displays the chemical composition of the extracts and reveals the presence of polyphenols, triterpenes and sterols in all extracts. Coumarins, flavonoids, alkaloids, saponins and tannins were selectively distributed.

\section{Cytotoxicity}

The results of the antiproliferative activity of the tested extracts and doxorubicin as determined by the NR uptake assay are shown in Table 2 . The selectivity index (Table 2) was determined as the ratio of $\mathrm{IC}_{50}$ value in the CRL2120 normal fibroblast, divided by the $\mathrm{IC}_{50}$ in the cancer cell line. Extracts EMW, KCL and doxorubicin had $\mathrm{IC}_{50}$ values below $40 \mu \mathrm{g} / \mathrm{mL}$ in the five studied carcinoma cell lines. The $\mathrm{IC}_{50}$ values of PCL were not detected at up to $40 \mu \mathrm{g} / \mathrm{mL}$ in all cancer cell lines whilst ECB, LAB and MML showed selective activities. The recorded $\mathrm{IC}_{50}$ values ranged from $3.29 \mu \mathrm{g} / \mathrm{mL}$ (towards DLD-1 colorectal adenocarcinoma cells) to 24.38 
Table 2 Cytotoxicity of tested plant extracts and doxorubicin towards cancer cell lines and normal cells as determined by the neutral red assay

\begin{tabular}{|c|c|c|c|c|c|c|}
\hline \multirow[t]{2}{*}{ Samples } & \multicolumn{6}{|c|}{ Cell lines, $I C_{50}$ values in $\mu \mathrm{g} / \mathrm{mL}$ and selectivity index ${ }^{\mathrm{a}}$ (in bracket) } \\
\hline & A549 & SPC212 & HepG2 & DLD-1 & MCF-7 & CRL2120 \\
\hline \multirow[t]{2}{*}{ Elephantopus mollis (whole plant; EMW) } & $24.38 \pm 1.86$ & $4.05 \pm 0.69$ & $3.74 \pm 0.07$ & $3.29 \pm 0.04$ & $3.97 \pm 0.48$ & $>40$ \\
\hline & $(>1.64)$ & $(>9.89)$ & $(>10.70)$ & $(>12.18)$ & $(>10.08)$ & \\
\hline \multirow[t]{2}{*}{ Enantia chlorantha (bark; ECB) } & $>40$ & $25.16 \pm 1.30$ & $17.32 \pm 0.13$ & $>40$ & $>40$ & $>40$ \\
\hline & & $(>1.59)$ & $(>12.31)$ & & & \\
\hline \multirow[t]{2}{*}{ Kalanchoe crenata (leaves; KCL) } & $8.23 \pm 0.15(>4.86)$ & $2.33 \pm 0.23$ & $28.96 \pm 3.51$ & $23.87 \pm 1.69$ & $19.31 \pm 0.79$ & $>40$ \\
\hline & & $(>17.20)$ & $(>1.38)$ & $(>1.68)$ & $(>2.07)$ & \\
\hline \multirow[t]{2}{*}{ Lophira alata (bark; LAB) } & $>40$ & $>40$ & $32.98 \pm 4.20$ & $>40$ & $>40$ & $>40$ \\
\hline & & & $(>1.21)$ & & & \\
\hline \multirow[t]{2}{*}{ Millettia macrophylla (leaves; MML) } & $>40$ & $7.54 \pm 0.26$ & $2.01 \pm 0.04$ & $31.02 \pm 2.86$ & $25.99 \pm 1.68$ & $>40$ \\
\hline & & $(>5.31)$ & $(>19.90)$ & $(>1.29)$ & $(>1.54)$ & \\
\hline Phragmanthera capitata (leaves; PCL) & $>40$ & $>40$ & $>40$ & $>40$ & $>40$ & $>40$ \\
\hline \multirow[t]{2}{*}{ Doxorubicin } & $0.55 \pm 0.11$ & $0.04 \pm 0.01$ & $0.10 \pm 0.01$ & $0.20 \pm 0.02$ & $0.19 \pm 0.03$ & $0.32 \pm 0.06$ \\
\hline & $(0.58)$ & $(8.63)$ & (3.18) & $(1.58)$ & $(1.67)$ & \\
\hline
\end{tabular}

${ }^{a}$ The selectivity index was determined as the ratio of $\mathrm{IC}_{50}$ value in the CRL2120 normal fibroblasts divided by the $\mathrm{IC}_{50}$ in the cancer cell lines. In bold: significant activity $[7,23,24,45]$

(against small lung cancer A549 cells) for EMW, from $2.33 \mu \mathrm{g} / \mathrm{mL}$ (mesothelioma SPC212 cells) to $28.96 \mu \mathrm{g} / \mathrm{mL}$ (HepG2 hepatocarcinoma) for KCL, and from $0.04 \mu \mathrm{g} / \mathrm{mL}$ (towards SPC212 cells) to $0.55 \mu \mathrm{g} / \mathrm{mL}$ (towards A549 cells) for doxorubicin. All extracts including the two most active ones (EMW and KCL) were less toxic towards normal CRL2120 fibroblast than carcinoma cells (selectivity indexes above 1.00) (Table 2). The best extracts, EMW and KCL as well as doxorubicin were further tested for the effects on cell cycle

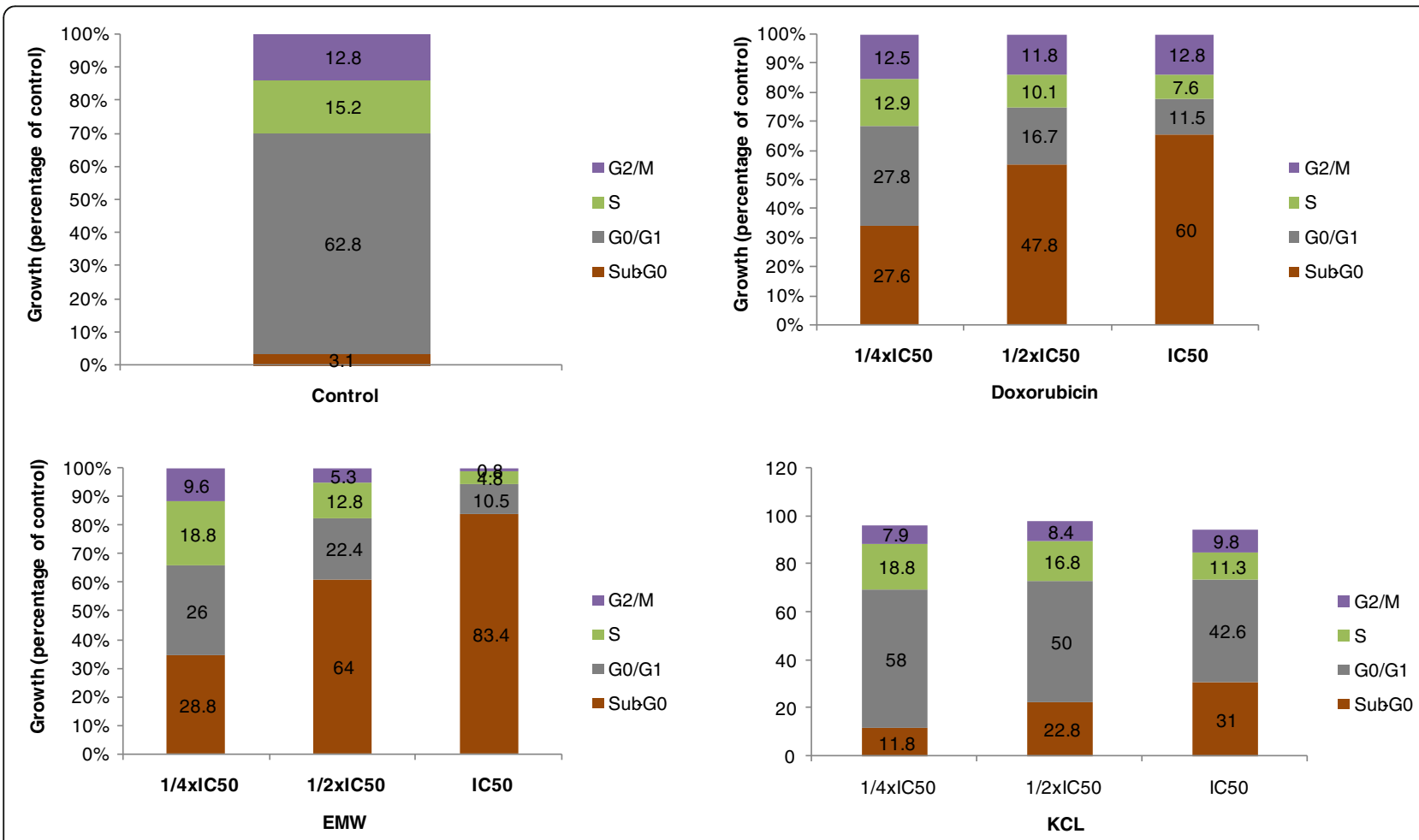

Fig. 1 Effects of the extracts from the whole plant of Elephantopus mollis (EMW), Kalanchoe crenata leaves (KCL) and doxorubicin on cell cycle distribution in MCF-7 cells. IC So $_{50}$ values were $3.97 \mu \mathrm{g} / \mathrm{mL}$ (EMW), $19.31 \mu \mathrm{g} / \mathrm{mL}$ (KCL) and $0.32 \mu \mathrm{g} / \mathrm{mL}$ (doxorubicin) 


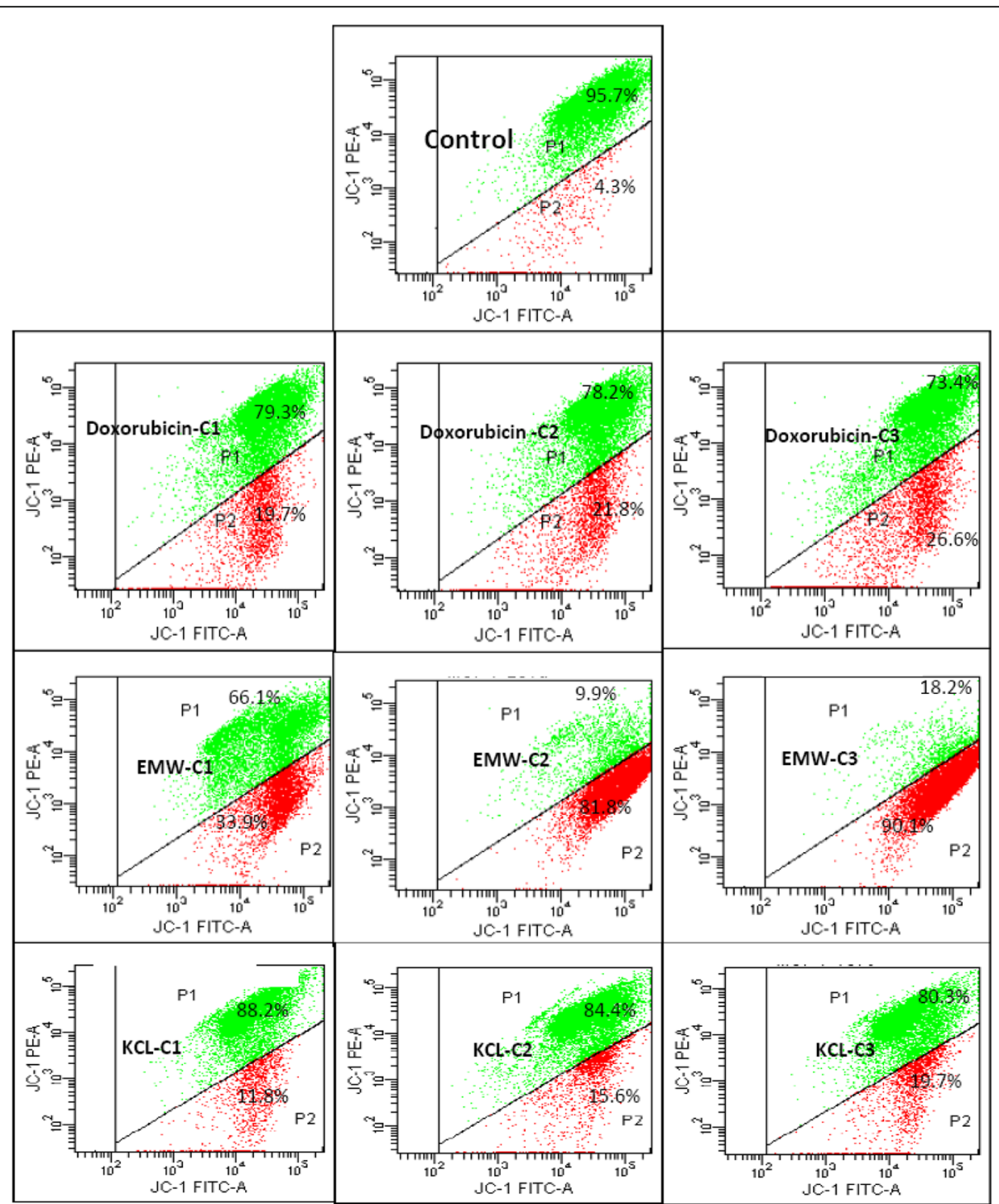

Fig. 2 Effects of Elephantopus mollis whole plant (EMW) and Kalanchoe crenata leaves (KCL) extracts and doxorubicin on MMP in MCF-7 cells for $72 \mathrm{~h}$. Cells were treated with $1 / 4 \times I C_{50}(C 1), 1 / 2 \times I C_{50}(C 2)$ and IC $C_{50}(C 3)$ of each compound. $I C_{50}$ values were $3.97 \mu \mathrm{g} / \mathrm{mL}(E M W), 19.31 \mu \mathrm{g} / \mathrm{mL}$ $(\mathrm{KCL})$ and $0.32 \mu \mathrm{g} / \mathrm{mL}$ (doxorubicin)

distribution, caspases activity, MMP loss and ROS production in MCF-7 cells.

\section{Mechanistic studies}

Cell cycle distribution in MCF-7 cells treated with EMM, KCL and doxorubicin is depicted in Fig. 1. EMW and KCL induced dose-dependent cell cycle modifications with progressive increase of sub-G0/G1 phase cells. Both EMW and KCL induced cell cycle arrest in G0/G1. Upon treatment of MCF-7 cells with the selected samples, they progressively underwent apoptosis; the increase of sub-G0/G1 cells ranged from $11.8 \%\left(1 / 4 \mathrm{IC}_{50}\right)$ to $31 \%\left(\mathrm{IC}_{50}\right)$ for $\mathrm{KCL}$, from $28.8 \%\left(1 / 4 \mathrm{IC}_{50}\right)$ to $83.4 \%\left(\mathrm{IC}_{50}\right)$ for EMW, from $27.6 \%\left(1 / 4 \mathrm{IC}_{50}\right)$ to $60 \%\left(\mathrm{IC}_{50}\right)$ for doxorubicin and only $3.1 \%$ in non-treated cells. Upon treatment of MCF-7 cells with EMW, KCL and doxorubicin with equivalent (eq.) to the $1 / 2 \times \mathrm{IC}_{50}$ and $\mathrm{IC}_{50}$ for $6 \mathrm{~h}$, no activation of caspase $3 / 7$ and caspase 9 activities was observed. MCF-7 cells were also treated with EMM, KCL and doxorubicin, and the integrity of the MMP was analyzed. Data shown in Fig. 2 indicate that treatments induced MMP loss, ranged from $33.9 \%$ at eq. to $1 / 4 \times \mathrm{IC}_{50}$ to $90.1 \%$ at eq. to the $\mathrm{IC}_{50}$ for $\mathrm{EMW}$, from $11.8 \%\left(1 / 4 \times \mathrm{IC}_{50}\right)$ to $19.7 \%\left(\mathrm{IC}_{50}\right)$ for $\mathrm{KCL}$ and $19.7 \%$ $\left(1 / 4 \times \mathrm{IC}_{50}\right)$ to $26.6 \%\left(\mathrm{IC}_{50}\right)$ for doxorubicin. Upon treatment of MCF-7 cells with the selected at concentration eq. to $1 / 4 \times \mathrm{IC}_{50}, 1 / 2 \times \mathrm{IC}_{50}$ and $\mathrm{IC}_{50}$ values for $24 \mathrm{~h}$, the production of ROS in cells was also analyzed (Fig. 3). EMW and KCL induced increased ROS levels of more than 3-folds (at $\mathrm{IC}_{50}$ ), as compared with non-treated 


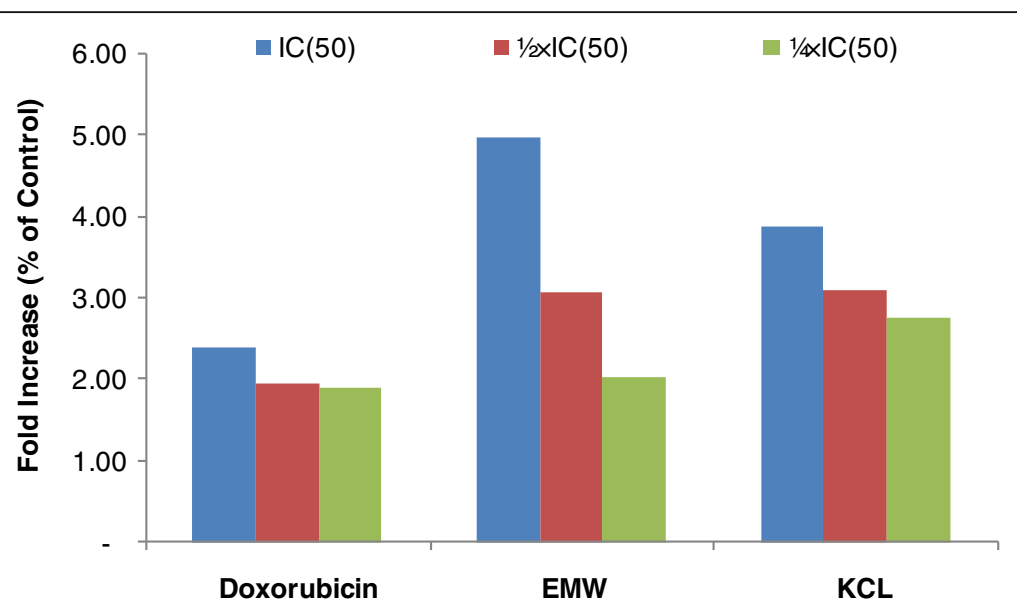

Fig. 3 Effects of Elephantopus mollis whole plant (EMW) and Kalanchoe crenata leaves (KCL) extracts and doxorubicin for $24 \mathrm{~h}$ in ROS production in MCF-7 cells after treatment with. $\mathrm{IC}_{50}$ values were $3.97 \mu \mathrm{g} / \mathrm{mL}$ (EMW), $19.31 \mu \mathrm{g} / \mathrm{mL}$ (KCL) and $0.32 \mu \mathrm{g} / \mathrm{mL}$ (doxorubicin)

cells whilst doxorubicin induced more than 2 -folds increase.

\section{Discussion}

Cancers appear as the leading cause of death globally, with 8.8 million deaths recorded in 2015 . The most killing types are cancers of the lungs (1.69 million deaths), liver (788,000 deaths), colon (774,000 deaths), stomach (754,000 deaths) and breasts (571,000 deaths) [21]. In this work, we assessed the ability of six medicinal plants used in cancer treatment or disease states with symptoms related to cancer, to prevent the proliferation of various carcinoma cell lines, including lung, liver, colon and breast cancers. These investigated cancer types are amongst the worldwide leading cause of cancer death $[21,22]$. Botanicals displaying $\mathrm{IC}_{50}$ values below $20 \mu \mathrm{g} / \mathrm{mL}$ have been said to be good cytotoxic samples $[7,23,24] . \mathrm{IC}_{50}$ values below $20 \mu \mathrm{g} / \mathrm{mL}$ were recorded with EMW, KCL, MML and ECB respectively in $4,3,2$ and 1 of the 5 tested carcinoma cells. Importantly, $\mathrm{IC}_{50}$ values below $5 \mu \mathrm{g} / \mathrm{mL}$ were obtained with EMW in 4/5 carcinoma cell lines as well as KCL towards SPC212 cells and MML against HepG2 cells. These data highlight the usefulness of these extracts in the fight against solid cancers. This hypothesis is strengthened by the good selectivity index $(\mathrm{SI}>1$; Table 2) of the tested extract, which is compatible with their possible use in cancer chemotherapy.

Elephantopus mollis and Millettia macrophylla are traditionally used in the treatment of cancers $[25,26]$. The two plants, Especiallye. mollis, had cytotoxic effects on the tested carcinoma cells, validating their traditional use in the management of malignancies. In this study, plants used traditionally to treat disease states with symptoms related to cancer, were Lophira alata, Enantia chlorantha, Phragmanthera capitata and Kalanchoe crenata. Amongst them, only P. capitata was not active on the tested cancer cell lines. This also consolidates the recommandations that ethnopharmacological usages such as immune and skin disorders, inflammatory, infectious, parasitic and viral diseases should be taken into account when selecting plants that treat cancer [27].

To the best of our knowledge, the anticancer activity of Enantia chlorantha, Lophira alata and Kalanchoe crenata is being reported herein for the first time. The antiproliferative effect of ethyl acetate extract of Elephantopus mollis, collected from Penang Agriculture Department, Relau, Malaysia), on HepG2 cells, with the lowest $\mathrm{IC}_{50}$ value of $9.38 \mu \mathrm{g} / \mathrm{mL}$, NCI-H23 cells $(13.17 \mu \mathrm{g} / \mathrm{mL}), \mathrm{T}-47 \mathrm{D}$ cells $(12.57 \mu \mathrm{g} / \mathrm{mL})$ and Caov-3 cells $(42.11 \mu \mathrm{g} / \mathrm{mL})[25,28]$, was reported. A much more lower $\mathrm{IC}_{50}$ value of $3.74 \mu \mathrm{g} / \mathrm{mL}$ was obtained with samples from Cameroon. This could be explained by possible geographic variations in the chemical constitution of the plant. However, both studies confirm the cytotoxic potential of this plant. The cytotoxicity of methanolic extract and chalcone dimers from $L$. alata on Ehrlich Ascites carcinoma cells [29] was also reported in the present work. This plant was moderately active against HepG2 cells, providing additional information on the anticancer activity of the plant. The poor cytotoxic effects of compounds and phenolic fractions of M. macrophylla towards breast cancer cells MCF-7 and MDA-MB-231, was reported [26]. Data obtained herein are in accordance with this previous study, as a moderate effect of MML was obtained in MCF-7 cells. However, MML had good effect against SPC212 lung adenocarcinoma and HepG2 adenocarcinoma cells, highlighting its possible use in the fight against cancers.

Finally, evidences of the antiproliferative effects of the tested plant extract, highlights the good activity of Elephantopus mollis, Kalanchoe crenata and in lesser 
extent Millettia macrophylla have been provided. Extract of E. mollis, induced apoptosis in MCF-7 cells, mediated by MMP loss and increased ROS production whilst Kalanchoe crenata leaves extract induced apoptosis via ROS production (Figs. 2 and 3). It should be noted that only ROS production is not enough to identify cell apoptosis. Therefore, additional studies including detection of other molecules related to apoptosis such as BCL2, BAX, PRPP, etc., will be performed. Purification of the most active plants (Elephantopus mollis, Kalanchoe crenata and Millettia macrophylla) will also be performed to identify their cytotoxic constituents.

\section{Conclusions}

In this work, the antiproliferative activity of extracts from six Cameroonian medicinal plants, Lophira alata, Enantia chlorantha, Phragmanthera capitata, Kalanchoe crenata, Elephantopus mollis and Millettia macrophylla was reported on five human solid cancer cell lines and normal CRL2120 fibroblasts. The three most active extracts were those from E. mollis whole plant, $K$. crenata leaves and M. macrophylla leaves. They can be used in the management of malignant diseases and deserve more exploration to isolate their active constituents in order to develop novel cytotoxic drugs.

\begin{abstract}
Abbreviations
ATCC: American Type Culture Collection; BAX: BCl-2-associated X protein; BCl2: B-cell lymphoma 2; DCF: 2',7'-dichlorofluorescein; DCFH: 2',7'-

dichlorodihydrofluorescin; DCFH-DA: 2',7'-dichlorodihydrofluorescin diacetate DMEM: Dulbecco's Modified Eagle Medium; DMSO: Dimethylsufoxide;

ECB: Enantia chlorantha bark extract; EDTA: Ethylenediaminetetraacetic acid; EMW: Elephantopus mollis extract; $\mathrm{H}_{2}$ DCFH-DA: 2',7'-

dichlorodihydrofluorescein diacetate; HNC: Cameroon National Herbarium; KCL: Kalanchoe crenata leaves extract; LAB: Lophira alata bark extract; MML: Millettia macrophylla leaves extract; MMP: Mitochondrial membrane potential; NR: Neutral red; PARP: Poly(ADP-ribose) polymerase;

PBS: Phosphate buffer saline; PCL: Phragmanthera capitata leaves extract; ROS: Reactive oxygen species
\end{abstract}

\section{Acknowledgments \\ V.K and H.S. are thankful to Scientific and Technological Research Council of Turkey (TÜBITAK) for 6 months travel grant (to V.K.) and to Scientific Research Projects Commission of Anadolu University, Eskisehir, Turkey for the funding grant 1507F563 (to V.K. and H.S.). A grant for part of this work was also provided by International Science Programme, Uppsala University, Sweden (ISP)-KEN-02 project. Authors are thankful to Şennur Görgülü for FACS measurements.}

\section{Availability of data and materials}

The datasets supporting the conclusions of this article are presented in this main paper.

\section{Authors' contributions}

VK, FWF and OK carried out the experiments; VK wrote the manuscript. VK, VPB and HS designed the experiments; HS supervised the work, provided the facilities for the study. All authors read the manuscript and approved the final version.

\section{Competing interests}

The authors declare that they have no competing interests.

\section{Consent for publication}

Not applicable in this section.

Ethic approval and consent to participate

Not applicable in this section.

\section{Publisher's Note}

Springer Nature remains neutral with regard to jurisdictional claims in published maps and institutional affiliations.

\section{Author details}

'Department of Biochemistry, Faculty of Science, University of Dschang, Dschang, Cameroon. ${ }^{2}$ Department of Biochemistry, Faculty of Science, University of Yaounde I, Yaounde, Cameroon. ${ }^{3}$ Department of Biology, Science Faculty, Anadolu University, Eskişehir, Turkey.

Received: 15 February 2017 Accepted: 15 May 2017

Published online: 25 May 2017

References

1. Stewart BW, Wild CP. In: IAfRo C, editor. World cancer report 2014. Lyon; 2014.

2. Omosa LK, Midiwo JO, Masila VM, Gisacho BM, Munayi R, Francisca K, et al. Cytotoxicity of 91 Kenyan indigenous medicinal plants towards human CCRF-CEM leukemia cells. J Ethnopharmacol. 2016;179:177-96.

3. Stevigny C, Bailly C, Quetin-Leclercq J. Cytotoxic and antitumor potentialities of aporphinoid alkaloids. Curr Med Chem Anticancer Agents. 2005;5(2):173-82.

4. Newman DJ, Cragg GM. Natural products as sources of new drugs over the last 25 years. J Nat Prod. 2007;70(3):461-77.

5. Newman DJ, Cragg GM. Natural products as sources of new drugs over the 30 years from 1981 to 2010. J Nat Prod. 2012;75(3):311-35.

6. Kuete V, Efferth T. Pharmacogenomics of Cameroonian traditional herbal medicine for cancer therapy. J Ethnopharmacol. 2011;137(1):752-66.

7. Kuete V, Efferth T. African flora has the potential to fight multidrug resistance of cancer. Biomed Res Int. 2015;2015:914813.

8. Kuete V, Djeussi DE, Mbaveng AT, Zeino M, Efferth T. Cytotoxicity of 15 Cameroonian medicinal plants against drug sensitive and multi-drug resistant cancer cells. J Ethnopharmacol. 2016;186:196-204.

9. Omosa LK, Midiwo JO, Masila VM, Gisacho BM, Munayi R, Francisca K, et al. Cytotoxicity of 91 Kenyan indigenous medicinal plants towards human CCRF-CEM leukemia cells. J Ethnopharmacol. 2015;179:177-96.

10. Harbone J (ed.): Phytochemical methods: a guide to modern techniques of plant analysis. London: Chapman \& Hall; 1973.

11. Ngameni B, Fotso GW, Kamga J, Ambassa P, Abdou T, Fankam AG, Voukeng IK, Ngadjui BT, Abegaz BM, Kuete V. 9 - Flavonoids and related compounds from the medicinal plants of Africa. In: Medicinal Plant Research in Africa. edn. Edited by Kuete V. Oxford: Elsevier; 2013: 301-350.

12. Wansi JD, Devkota KP, Tshikalange E, Kuete V. 14 - Alkaloids from the Medicinal Plants of Africa. In: Medicinal Plant Research in Africa. edn. Edited by Kuete V. Oxford: Elsevier; 2013: 557-605.

13. Poumale HMP, Hamm R, Zang Y, Shiono Y, Kuete V. 8 - Coumarins and Related Compounds from the Medicinal Plants of Africa. In: Medicinal Plant Research in Africa. edn. Edited by Kuete V. Oxford: Elsevier; 2013: 261-300.

14. Borenfreund $\mathrm{E}$, Babich $\mathrm{H}$, Martin-Alguacil N. Comparisons of two in vitro cytotoxicity assays-the neutral red (NR) and tetrazolium MTT tests. Toxicol in Vitro. 1988;2(1):1-6.

15. Repetto G, del Peso A, Zurita JL. Neutral red uptake assay for the estimation of cell viability/cytotoxicity. Nat Protoc. 2008;3(7):1125-31.

16. Kuete V, Omosa LK, Tala VR, Midiwo JO, Mbaveng AT, Swaleh S, et al. Cytotoxicity of plumbagin, rapanone and 12 other naturally occurring quinones from Kenyan flora towards human carcinoma cells. BMC Pharmacol Toxicol. 2016;17(1):60.

17. Kuete V, Krusche B, Youns M, Voukeng I, Fankam AG, Tankeo S, et al. Cytotoxicity of some Cameroonian spices and selected medicinal plant extracts. J Ethnopharmacol. 2011;134(3):803-12.

18. Kuete V, Sandjo L, Nantchouang Ouete J, Fouotsa H, Wiench B, Efferth T. Cytotoxicity and modes of action of three naturally occuring xanthones (8-hydroxycudraxanthone G, morusignin I and cudraxanthone I) against sensitive and multidrug-resistant cancer cell lines. Phytomedicine. 2013;21(3):315-22 
19. Kuete V, Fankam AG, Wiench B, Efferth T. Cytotoxicity and modes of action of the methanol extracts of six Cameroonian medicinal plants against multidrug-mesistant tumor cells. Evid Based Complement Alternat Med. 2013;2013:285903.

20. Kuete V, Tankeo SB, Saeed ME, Wiench B, Tane P, Efferth T. Cytotoxicity and modes of action of five Cameroonian medicinal plants against multi-factorial drug resistance of tumor cells. J Ethnopharmacol. 2014;153(1):207-19.

21. WHO: http://www.who.int/mediacentre/factsheets/fs297/en/. 2017. Accessed on February 12, 2017.

22. Torre LA, Bray F, Siegel RL, Ferlay J, Lortet-Tieulent J, Jemal A. Global cancer statistics, 2012. CA Cancer J Clin. 2015;65(2):87-108.

23. Boik J. Natural compounds in cancer therapy. Minnesota USA: Oregon Medical Press; 2001.

24. Brahemi G, Kona FR, Fiasella A, Buac D, Soukupova J, Brancale A, et al. Exploring the structural requirements for inhibition of the ubiquitin E3 ligase breast cancer associated protein 2 (BCA2) as a treatment for breast cancer. J Med Chem. 2010;53(7):2757-65.

25. Ooi KL, Tengku Muhammad TS, Lam LY, Sulaiman SF. Cytotoxic and apoptotic effects of ethyl acetate extract of Elephantopus mollis Kunth. In human liver carcinoma HepG2 cells through caspase-3 activation. Integr Cancer Ther. 2014;13(3):NP1-9.

26. Zingue S, Tchoumtchoua J, Ntsa DM, Sandjo LP, Cisilotto J, Nde CB, et al. Estrogenic and cytotoxic potentials of compounds isolated from Millettia macrophylla Benth (Fabaceae): towards a better understanding of its underlying mechanisms. BMC Complement Altern Med. 2016;16(1):421.

27. Fitzmaurice C, Dicker D, Pain A, Hamavid H, Moradi-Lakeh M, Maclntyre MF, et al. The global burden of cancer 2013. JAMA Oncol. 2015;1(4):505-27.

28. Daisy $P$, Jasmine $R$, Ignacimuthu $S$, Murugan $E$. A novel steroid from Elephantopus scaber $\mathrm{L}$. an ethnomedicinal plant with antidiabetic activity. Phytomedicine. 2009;16(2-3):252-7.

29. Ajiboye TO, Yakubu MT, Oladiji AT. Cytotoxic, antimutagenic, and antioxidant activities of methanolic extract and chalcone dimers (lophirones B and C) derived from Lophira alata (van Tiegh. Ex Keay) stem bark. J Evid Based Complementary Altern Med. 2014;19(1):20-30.

30. Adjanohoun J, Aboubakar N, Dramane K, Ebot M, Ekpere J, Enow-Orock E, et al. Traditional medicine and pharmacopoeia: contribution to ethnobotanical and floristic studies in Cameroon. OUA/STRC: Lagos; 1996.

31. Adebiyi OE, Abatan MO. Phytochemical and acute toxicity of ethanolic extract of Enantia chlorantha (oliv) stem bark in albino rats. Interdiscip Toxicol. 2013;6(3):145-51.

32. Agbaje EO, Onabanjo AO. Toxicological study of the extracts of antimalarial medicinal plant Enantia chlorantha. Cent Afr J Med. 1994;40:71-3.

33. Adesokan AA, Akanji MA, Yakubu MT. Antibacterial potentials of aqueous extract of Enantia chlorantha stem bark. Afr J Biotechnol. 2007:6:2502-5.

34. Ooi KL, Muhammad TS, Tan ML, Sulaiman SF. Cytotoxic, apoptotic and antialpha-glucosidase activities of 3,4-di-O-caffeoyl quinic acid, an antioxidant isolated from the polyphenolic-rich extract of Elephantopus mollis Kunth. J Ethnopharmacol. 2011;135(3):685-95.

35. Kamgang R, Foyet AF, Essame JL, Ngogang JY. Effect of methanolic fraction of Kalanchoe crenata on metabolic parameters in adriamycin-induced renal impairment in rats. Indian J Pharmacol. 2012:44(5):566-70.

36. Akinsulire $\mathrm{OR}$, Aibinu IE, Adenipekun T, Adelowotan T, Odugbemi T. In vitro antimicrobial activity of crude extracts from plants Bryophyllum pinnatum and Kalanchoe crenata. Afr J Tradit Complement Altern Med. 2007;4(3):338-44.

37. Kamgang R, Mboumi RY, Fondjo AF, Tagne MA, N'Dille GP, Yonkeu JN. Antihyperglycaemic potential of the water-ethanol extract of Kalanchoe crenata (Crassulaceae). J Nat Med. 2008;62(1):34-40.

38. Nguelefack TB, Nana P, Atsamo AD, Dimo T, Watcho P, Dongmo AB, et al. Analgesic and anticonvulsant effects of extracts from the leaves of Kalanchoe crenata (Andrews) Haworth (Crassulaceae). J Ethnopharmacol. 2006;106(1):70-5

39. Falade MO, Akinboye DO, Gbotosho GO, Ajaiyeoba EO, Happi TC, Abiodun $\mathrm{OO}$, et al. In vitro and in vivo antimalarial activity of Ficus thonningii Blume (Moraceae) and Lophira alata banks (Ochnaceae), identified from the ethnomedicine of the Nigerian Middle Belt. J Parasitol Res. 2014;2014:972853.

40. Murakami A, Tanaka S, Ohigashi H, Hirota M, Irie R, Takeda N, et al. Chalcone tetramers, lophirachalcone and alatachalcone, from Lophira alata as possible anti-tumor promoters. Biosci Biotechnol Biochem. 1992:56(5):769-72.
41. Tih AE, Ghogomu RT, Sondengam BL, Caux C, Bodo B. minor Biflavonoids from Lophira alata leaves. J Nat Prod. 2006:69(8):1206-8.

42. Abderamane B, Tih AE, Ghogomu RT, Blond A, Bodo B. Isoflavonoid derivatives from Lophira alata stem heartwood. Z Naturforsch C. 2011;66(3-4):87-92.

43. Lenta BN, Ateba JT, Chouna JR, Aminake MN, Nardella F, Pradel G, et al. Two 2,6-Dioxabicyclo[3.3.1]nonan-3-ones from Phragmanthera capitata (Spreng.) Balle (Loranthaceae). Helvet Chim Acta. 2015;98(7):945-52.

44. Galani BR, Sahuc ME, Njayou FN, Deloison G, Mkounga P, Feudjou WF, et al. Plant extracts from Cameroonian medicinal plants strongly inhibit hepatitis C virus infection in vitro. Front Microbiol. 2015;6:488.

45. Kuete V, Efferth T. Cameroonian medicinal plants: pharmacology and derived natural products. Front Pharmacol. 2010;1:123.

\section{Submit your next manuscript to BioMed Central and we will help you at every step:}

- We accept pre-submission inquiries

- Our selector tool helps you to find the most relevant journal

- We provide round the clock customer support

- Convenient online submission

- Thorough peer review

- Inclusion in PubMed and all major indexing services

- Maximum visibility for your research

Submit your manuscript at www.biomedcentral.com/submit
Biomed Central 